\title{
МЕТОД РЕГИСТРАЦИИ ИК-ИЗЛУЧЕНИЯ НЕОХЛАЖДАЕМЫМ ФОТОПРИЕМНИКОМ
}

\author{
И. А. ИВАНЧЕНКО, Л. М. БУДИЯНСКАЯ, В. И. САНТОНИЙ, В. А. СМЫНТЫНА \\ Одесский нащиональный университет имени И. И. Мечникова, \\ Украина, Одесса, 65000, ул. Дворянськая 2
}

\begin{abstract}
Аннотация. Описан оптический метод регистрации излучения в дальней ИК-области спектра на фоне теплового шума при помощи неохлаждаемого фотоприемника (ФП), что актуально для области индикаторных сенсоров. Основой ФП является резкий анизотипный гетеропереход, выполненный по схеме «оптическое окно-поглотитель». Рассмотрен механизм возникновения составляющих фототока в гетеропереходе при поглощении длинноволнового излучения и их соотношение. Предложено измерение фототока в ФП путем включения гетеропереходной структуры в мостовую схему. Приведено аналитическое описание зависимости контурных токов от элементов эквивалентной схемы гетероперехода и мостовой схемы измерений. Установлено, что функциональные зависимости составляющих фототока через структурные элементы гетероперехода противоположны по знаку и пересекаются в точке равенства их значений. Метод позволяет разделить токи в слоях гетероперехода, рассчитать или установить путем регулирования схемы измерений опорное значение тока и обеспечить измерение фототока меньше теплового фонового по величине. Приведен пример практической реализации метода в гетеропереходном ФП со структурой $n(\mathrm{CdSe})-p\left(\mathrm{~Pb}_{1-\mathrm{x}} \mathrm{Sn}_{\mathrm{x}} \mathrm{Se}\right)$.
\end{abstract}

Ключевые слова: ИК-излучение; фотоприемник; гетеропереход; эквивалентная схема; тепловой фон; схема измерений

Трудности измерений излучения в дальней ИК-области спектра (1 10 мкм) связаны с тем, что на данную спектральную область приходится тепловое излучение фоновых объектов, которое является источником теплового шума фотоприемника (ФП). При этом отношение сигнал/шум не достигает 1, что исключает возможность выделения измерительного сигнала.

Для достижения необходимого отношения сигнал/шум применяется криогенное охлаждение ФП до температуры 80-150 К с целью уменьшения количества термогенерированных носителей заряда.

Известны охлаждаемые устройства регистрации излучения в дальней ИК-области, основанные на прямом измерении как собствен- ной фотопроводимости в ФП на основе узкозонных твердых растворов $\mathrm{CdHgTe} \mathrm{и} \mathrm{PbSnTe}$ $[1,2]$, так и несобственной фотопроводимости в ФП из легированного Ge [3], а также поглощении излучения свободными носителями и др. [4].

Поскольку применение охлаждаемых ФП затруднительно и не всегда целесообразно, например, в качестве индикаторных сенсоров, то создание неохлаждаемых ФП в данной области спектра достаточно актуально.

Задачей исследования является создание метода регистрации ИК-излучения на фоне теплового шума при помощи неохлаждаемого $\Phi \Pi$.

Для обнаружения ИК-излучения предложен ФП с гетеропереходной структурой 


\section{БИБЛИОГРАФИЧЕСКИЙ СПИСОК}

1. Сизов, Ф.Ф. Фотоэлектроника для систем видения в «невидимых» участках спектра. К.: Академпериодика, 2008. $460 \mathrm{c.}$

2. Сизов, Ф.Ф.ИК-фотоэлектроника: фотонные или тепловые детекторы? Перспективы. Сенсорная электроника и микросистемные технологии, Т. 12, № 1, C. 26-52, 2015. URL: http://semst.onu.edu.ua/article/ view/104447.

3. Rogalski, A. Far-infrared semiconductor detectors and focal plane arrays, in: $\mathrm{THz}$ and Security Applications [ed. by K. Corsi, F. Sizov]. Springer, 2014. P. 25-52. DOI: 10.1007/978-94-017-8828-1.

4. Gilmore, A. S. High-definition infrared FPAs. Technology Today, No. 1, P. 4-8, 2008. URL: http://www. raytheon.com/news/technology today/archive/2008 issu el.pdf.
5. Сальков, Е.А. Основы полупроводниковой фотоэлектроники. К.: Наукова думка, 1988. 280 с.

6. Сердюк, В.В. Физика солнечных элементов. Одесса: Логос, 1994. 333 с.

7. Іванченко, І. О.; Будіянська, Л.М.; Сминтина, В. А.; Сантоній, В. І. Метод виявлення інфрачервоного випромінювання. Патент України № 106203 G01N 21/47, 21/55, публ. 25.04.2016.

8. Бычков, Ю.А.; Золотницкий, В.А.; Чернышов Э.П. (ред.). Теоретические основы электротехники. Справочник по теории электрических ичепей. Питер, 2008. $349 \mathrm{c}$.

9. Бронштейн, И.Н.; Семендяев, К. А. Справочник по математике для инженеров и учащихся втузов. М.: Наука, 1986. 544 с.

10. Lepikh, Y. I.; Ivanchenko, I. A.; Budiyanskaya, L. M. Uncooled $p\left(\mathrm{~Pb}_{1-\mathrm{x}} \mathrm{Sn}_{\mathrm{x}} \mathrm{Se}\right)-n(\mathrm{CdSe})$ heterostructure-based photodetector for the far infrared spectral range. Semiconductor Physics, Quantum Electronics \& Optoelectronics, Vol. 17, No. 4, P. 408-411, 2014. PACS 07.57.Kp, 73.40.-c. 